\title{
Efficacy of Andrographis paniculata against extended spectrum $\beta$-lactamase (ESBL) producing $E$. coli
}

\author{
Ubaid Rasool $^{\dagger}$, Priya $\mathrm{S}^{\dagger}$, Afsana Parveen, Saroj Kumar Sah and Hemalatha S $^{*}$
}

\begin{abstract}
Background: A. paniculata is widely known for its medicinal values and is traditionally used to treat a wide range of diseases such as cancer, diabetes, skin infections, influenza, diarrhoea, etc. The phytochemical constituents of this plant possess unique and interesting biological activities. The main focus of this study was to evaluate the antibacterial property of crude ethyl acetate (CEA) extract of $A$. paniculata against $E$. coli clinical isolates along with molecular docking of 10 different bioactive components from this plant with CTX-M-15.

Methods: CEA extract was subjected to phytochemical and FTIR analysis. The E. coli isolates were tested for antibiotic susceptibility through disk-diffusion method to observe their resistance pattern towards different antibiotics. Antibacterial activity and biofilm assay were performed through broth microdilution using a 96-well microplate. CEA extract was further utilized to observe its effect on the expression of a gene encoding CTX-M-15. Finally, in-silico studies were performed where 10 different bioactive compounds from A. paniculata were molecularly docked with CTX-M-15.
\end{abstract}

Results: Phytochemical and FTIR analysis detected the presence of various secondary metabolites and functional groups in CEA extract respectively. Molecular docking provided the number of residues and bond lengths together with a positive docking score. Antibiotic susceptibility showed the multi-drug resistance of all the clinical strains of E. coli. The antibacterial and antibiofilm efficiency of CEA extract $(25,50$ and $100 \mu \mathrm{g} / \mathrm{ml})$ was tested and $100 \mu \mathrm{g} / \mathrm{ml}$ of the extract was more effective in all the strains of $E$. coli. All 3 ESBL producing strains of $E$. coli were subjected to gene expression analysis through PCR. Strains treated with $100 \mu \mathrm{g} / \mathrm{ml}$ of the extract showed a downregulation of the gene encoding CTX-M-15 compared to untreated controls.

Conclusions: The utilization of CEA extract of A. paniculata proved an economical way of controlling the growth and biofilm formation of ESBL strains of E. coli. CEA extract was also able to downregulate the expression of a gene encoding CTX-M-15. Molecular docking of 10 different bioactive compounds from A. paniculata with CTX-M-15 provided the residues and bond lengths with a positive docking score.

Keywords: A. paniculata, ESBL, Antibacterial, Molecular docking, Gene expression

\footnotetext{
* Correspondence: hemalatha.sls@bsauniv.ac.in

†Ubaid Rasool and S. Priya contributed equally to this work.

School of Life Sciences, B.S. Abdur Rahman Crescent Institute of Science and

Technology, Vandalur, Chennai 600048, India
}

(c) The Author(s). 2018 Open Access This article is distributed under the terms of the Creative Commons Attribution 4.0 International License (http://creativecommons.org/licenses/by/4.0/), which permits unrestricted use, distribution, and reproduction in any medium, provided you give appropriate credit to the original author(s) and the source, provide a link to the Creative Commons license, and indicate if changes were made. The Creative Commons Public Domain Dedication waiver (http://creativecommons.org/publicdomain/zero/1.0/) applies to the data made available in this article, unless otherwise stated. 


\section{Background}

Andrographis paniculata is widely used for medicinal purposes $[1,2]$. The primary component of this plant that possesses medicinal values is andrographolide, a diterpene lactone which has been reported by various researchers as anti-cancerous [3], anti-HIV [4], cardioprotective [5], hepatoprotective [6] apart from other medically important values. The other active components that are present in $A$. paniculata include andrographolide $\mathrm{D}$, homoandrographolide, andrographosterin and stigmasterol [7]. Zaiden and co-workers reported the antimicrobial effect of water extracts of $A$. paniculata against both Gram-positive and Gram-negative bacteria [8]. Bobbarala and co-workers reported higher antibacterial activity of methanolic extracts of A. paniculata (95\% inhibition of test organisms) compared to chloroform (80\% inhibition of test organisms) and hexane (65\% inhibition of test organisms) extracts [9].

The main motive behind this study was to study the effect of CEA extract of $A$. paniculata on the growth and biofilm formation in 3 ESBL producing strains and one ATCC strain of E. coli together with in-silico studies. $E$. coli strains were also subjected to DNA isolation and gene expression analysis through polymerase chain reaction (PCR) to study the effect of CEA extract on the expression of a gene encoding CTX-M-15.

\section{Methods}

\section{Bacterial strains and A. paniculata leaves}

ESBL strains were collected from Tagore Medical College, Chennai, India after a proper approval from the institutional ethics committee. ATCC strain of E. coli was provided from the departmental stock at School of Life Sciences, BSACIST. All the strains were properly sub-cultured and maintained as glycerol stocks and slants. The Andrographis paniculata leaves were collected from BSACIST, Chennai. The samples were identified and authenticated by Dr. D. Narasimhan, Botanist, Madras Christian College, Chennai. A specimen of the plant was deposited at School of Life Sciences, BSACIST, Chennai (Accession number: SLS-BSAU-16100).

\section{Sample preparation, solvent extraction and phytochemical analysis}

Leaves of $A$. paniculata were collected and dried in hot air oven at $60{ }^{\circ} \mathrm{C}$ and were crushed to powder. $50 \mathrm{~g}$ of the powder was soaked in $250 \mathrm{ml}$ of ethyl acetate and incubated in a shaker for $48 \mathrm{~h}$ followed by filtration through Whatman filter paper. The extracted residue was air dried and a stock concentration of $1 \mathrm{mg} / \mathrm{ml}$ was prepared. The CEA extract was qualitatively tested for the presence of tannins, flavonoids, carbohydrates, terpenoids, saponins and amino acids [10-12].

\section{FTIR analysis}

CEA extract of $A$. paniculata was subjected to FTIR analysis to get a knowledge about the functional groups present. FTIR analysis is an established tool that is very helpful in characterizing and identifying various functional groups that may be available in any unidentified plant extract $[13,14]$. Both liquids, as well as solid samples, can be used to carry out this analysis [15].

\section{In-silico studies}

Molecular docking of 10 different active components of A. paniculata was carried out with CTX-M-15. SYBYL ${ }^{\circ}$-X 1.3 (http://www.tripos.com) was the software package used to carry out the calculations. This software package runs on 32 or 64-bit operating systems (Windows XP SP3 and Windows 7).

\section{Ligand preparation}

A total of 38 bioactive compounds from A. paniculata were selected, out of which 10 bioactive compounds were finally chosen for molecular docking studies. The three-dimensional structures of all the bioactive compounds used were retrieved from PubChem and the final optimized ligands were used for molecular docking.

\section{Protein structure preparation}

The crystal structure of bacterial target protein CTX-M-15 (PBD ID: 5 T66) was retrieved from the PDB database (http://www.rcsb.org) [16]. Receptor protein was made free from all the crystallographic substructures and water molecules. This was followed by the addition of necessary hydrogen atoms and charges along with Gasteiger-Marsili. Trivial portable operating system (TRIPOS) was employed for the minimization process and protein ProtoMol was automatically generated. The final structure was viewed using PyMOL (http:// www.pymol.org).

\section{Molecular docking}

Molecular docking is a tool that helps in predicting the orientation of one molecule to a second when they are bound to each other forming a stable complex. That orientation, in turn, may be used for the prediction of binding affinity or the strength with which the two molecules are associated. Docking finds an important role in rational drug designing through the prediction of orientation between drug molecules and their protein targets [17]. In this particular study, a total of 10 compounds were docked with CTX-M-15 protein to get the binding affinities, hydrogen bonds and hydrophobic interactions. 


\section{Antibiotic susceptibility testing and phenotypic ESBL detection}

Susceptibility testing of clinical isolates and an ATCC strain of $E$. coli was evaluated via disk diffusion method as described by Ekwealor et al. (2016) with some slight modifications [18]. LBA plates were prepared and seeded with an overnight culture of all three clinical isolates and an ATCC strain of E. coli. Following antibiotic discs were used for susceptibility testing: Amoxicillin $(25 \mu \mathrm{g} /$ disc), Amoxicillin and clavulanic acid (20/10 $\mu \mathrm{g} /$ disc), Cefotetan $(30 \mu \mathrm{g} /$ disc $)$, Aztreonam $(30 \mu \mathrm{g} / \mathrm{disc})$, Ceftazidime $(30 \mu \mathrm{g} /$ disc $)$, Ceftriaxone $(30 \mu \mathrm{g} /$ disc $)$, Cefazolin (30 $\mu \mathrm{g} /$ disc). A single disc of each antibiotic was placed on the plates seeded with the overnight cultures of the bacterial isolates. Phenotypic ESBL detection was carried out through combined disc diffusion test following clinical laboratory standard Institute (CLSI) guidelines [19]. Each plate seeded with a clinical isolate of $E$. coli was subjected to phenotypic ESBL confirmatory test by placing two antibiotic discs of ceftazidime and ceftazidime + clavulanic acid. A $5 \mathrm{~mm}$ increase in the zone of CAZ + CA compared to CA was considered as ESBL positive. All susceptibility as well as ESBL confirmatory test plates were incubated at $37^{\circ} \mathrm{C}$ for $24 \mathrm{~h}$ and were observed for the zone of inhibition.

\section{Multiple antibiotic resistance indices (MARI)}

MARI calculations for all the clinical isolates and an ATCC strain of E. coli were carried out by dividing the number of antibiotics to which the bacteria showed resistance by the total number of antibiotics to which the bacteria were subjected [18]. MARI calculations were carried out for all three clinical isolates and an ATCC strain of E. coli.

Antibacterial activity through broth microdilution method In vitro antibacterial activity of CEA extract against three ESBL producing and one ATCC strain of E. coli was performed through the modified broth microdilution method [20] using a 96-well microplate. Three different dilutions of CEA extract (25, 50 and $100 \mu \mathrm{g})$ were prepared with LB broth and overnight cultures of all $E$. coli strains, adjusted to $0.5 \mathrm{McFarland}$ standard, were added to the prepared dilutions. Positive and negative controls were properly used. The plate was incubated at $37{ }^{\circ} \mathrm{C}$ for $12-24 \mathrm{~h}$ and the growth of all $E$. coli strains was observed as turbidity using a microplate reader (EnSpireTM Multilabel Reader 2300, S.No. 2300096) at $600 \mathrm{~nm}$. The obtained values were graphically plotted. This experiment was performed in triplicates.

Biofilm assay using a 96-well microplate

In vitro biofilm inhibition potential of CEA extract against three ESBL and one ATCC strains of E. coli was performed as described [21]. Three different dilutions of CEA extract $(25,50$ and $100 \mu \mathrm{g})$ were prepared with LB broth and all E. coli strains, adjusted to 0.5 McFarland standard, were added to the prepared dilutions. Positive and negative controls were properly used. The plate was incubated at $37{ }^{\circ} \mathrm{C}$ and $200 \mathrm{rpm}$ in an incubator shaker for $12-48 \mathrm{~h}$. The cells were later discarded and the plate was washed with distilled water in order to remove the unattached cells. $0.1 \%$ of crystal violet stain was added to each well and the plate was incubated at room temperature for $10 \mathrm{~min}$. Excess stain was removed by washing so as to decrease the background staining. The plate was kept for drying overnight and 30\% glacial acetic acid was added to each well. Spectrophotometric measurements were recorded at $517 \mathrm{~nm}$ and the obtained values were graphically plotted. This experiment was performed in triplicates.

\section{DNA isolation and gene expression analysis by polymerase chain reaction (PCR)}

Three ESBL strains of $E$. coli were subjected to DNA isolation and gene expression analysis through PCR. All strains were treated with $100 \mu \mathrm{g} / \mathrm{ml}$ of CEA extract of $A$. paniculata and incubated at $37^{\circ} \mathrm{C}$ for $24 \mathrm{~h}$. Strains without treatment served as controls. After proper incubation, $1 \mathrm{ml}$ of solution from each tube was transferred to $1.5 \mathrm{ml}$ Eppendorf tubes and centrifuged at $12000 \mathrm{rpm}$ for $5 \mathrm{~min}$. The supernatant was discarded and the pellet was washed with distilled water. Finally, $250 \mu \mathrm{l}$ of autoclaved distilled water was added to the pellet, tubes were placed in a thermostat at $100{ }^{\circ} \mathrm{C}$ for $10 \mathrm{~min}$ (heat lysis) and then centrifuged at $12000 \mathrm{rpm}$. The supernatant was transferred to another tube and stored at $-80{ }^{\circ} \mathrm{C}$ for Agarose gel electrophoresis [22].

DNA samples from all the isolates were amplified with bla $_{\text {CTX-M-15 }}$ gene. The amplification was carried out on a Mastercycler nexus gradient (Eppendorf, USA). The reaction mixtures comprised of $5 \mu$ l of $2 \times$ Redeye Master Mix (Amplicon III), $2 \mu \mathrm{l}$ of 1 M CTX-M-15 forward

Table 1 Wave number and the corresponding possible functional groups present in the extract

\begin{tabular}{lll}
\hline S No & Wavenumber $\left(\mathrm{cm}^{-1}\right)$ & Functional groups \\
\hline 1 & 413.656 & Bromide. lodide \\
2 & 607.467 & Chloroalkanes \\
3 & 1037.52 & Amines \\
4 & 1241.93 & Alkyl Halide \\
5 & 1373.07 & Alkane \\
6 & 1447.31 & Alkane or Organophosphorus \\
7 & 1734.66 & Carbonyl \\
8 & 2860.88 & Aldehyde \\
9 & 2927.41 & Alkanes and Alkyls \\
\hline
\end{tabular}



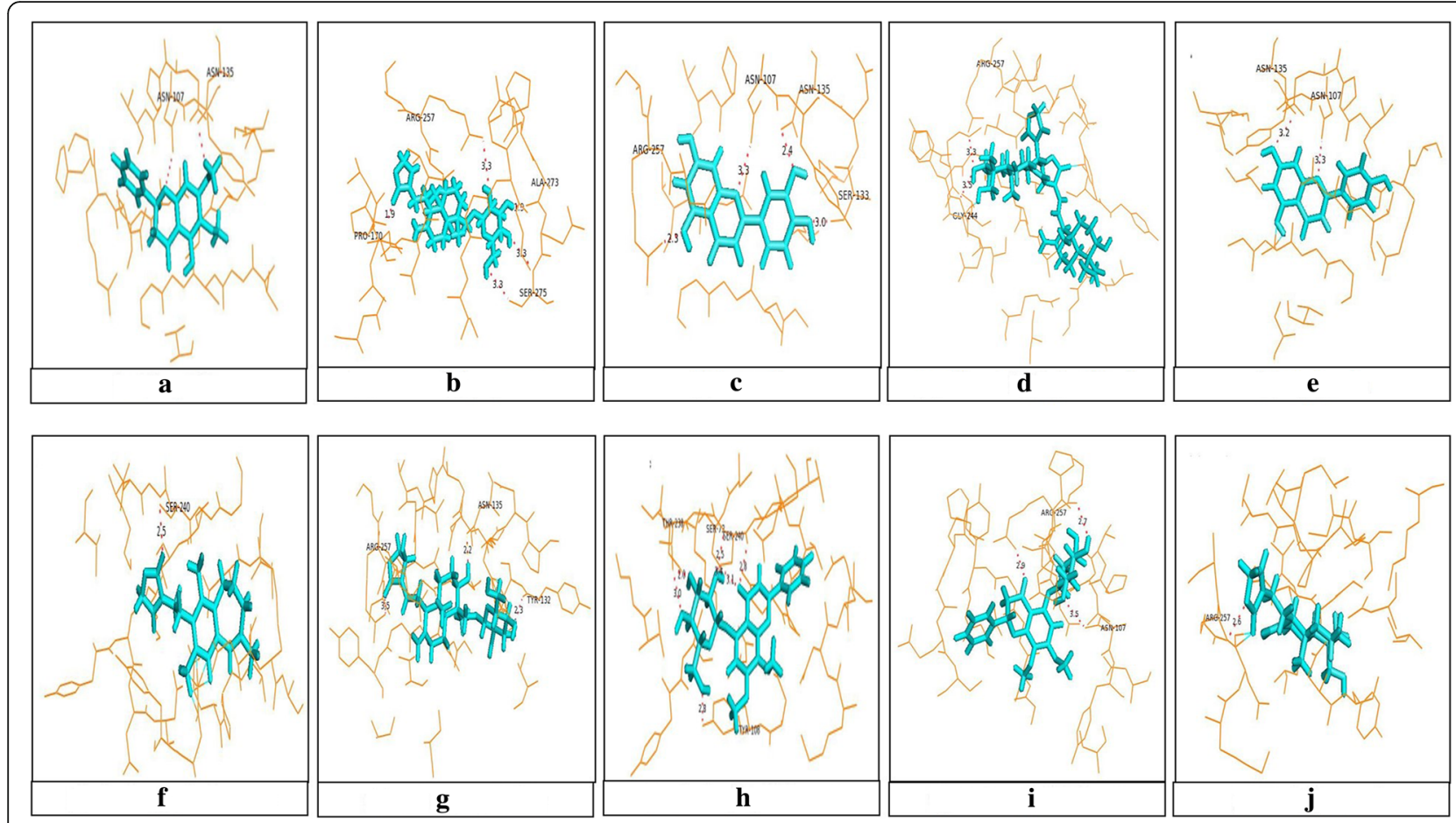

Fig. 1 Molecular docking of CTX-M-15 with 10 different bioactive compounds from A. paniculata. a Onysilin, b Neoandrographolide, c Luteolin, d Bisandrographolide A, e Apigenin, f Andrographolactone, $\mathbf{g}$ Andrographiside, $\mathbf{h}$ Andrographidine C, i Andrographidine A, j Andrograpanin

(CACGTCAATGGGACGATGT) and reverse (GAAA GGCAATACCACCGGT) primer each and $3.0 \mu \mathrm{l}$ of template DNA. The final reaction volume was $10 \mu \mathrm{l}$. The amplification reaction was carried out as the follows: Initial denaturation at $94{ }^{\circ} \mathrm{C}$ for $5 \mathrm{~min}$, accompanied by 35 cycles of denaturation at $95{ }^{\circ} \mathrm{C}$ for the $30 \mathrm{~s}$, annealing at $55^{\circ} \mathrm{C}$ and extension at $70{ }^{\circ} \mathrm{C}$ for $1 \mathrm{~min}$, and the final extension at $72{ }^{\circ} \mathrm{C}$ for $10 \mathrm{~min}$. The PCR product was analyzed by electrophoresis in 1.5\% $\mathrm{w} / \mathrm{v}$ agarose gel at $60 \mathrm{~V}$ for $60 \mathrm{~min}$. 1× Tris-acetate- EDTA buffer (1X TAE buffer), $\mathrm{pH}-7.6,20 \mathrm{mM}$ acetic acid, $1 \mathrm{mM}$ EDTA) and 100 bp DNA ladder (Gene Direx) was used. The gel was stained using ethidium bromide and imaged under ChemiDoc MP System (Bio-Rad, USA 2013) after $1 \mathrm{~h}$ of electrophoresis.

\section{Results}

\section{Phytochemical and FTIR analysis}

The CEA extract of $A$. paniculata was subjected to qualitative phytochemical analysis and it was observed that the extract tested positive for terpenoids and saponins whereas the extract tested negative for tannins, flavonoids, carbohydrates and amino acids. FTIR analysis of $A$. paniculata extract was carried out to identify the functional groups present in the extract. The wavenumbers and their corresponding functional groups are presented in Table 1. An Additional file 1 gives a diagrammatic representation of the FTIR spectrum obtained.

\section{In-silico studies}

The three-dimensional structures of all 10 bioactive compounds were retrieved from PubChem and the final optimized ligands were used for molecular docking. Docking analysis of CTX-M-15 with the 10 bioactive compounds along with the residues and the bond length of each compound is shown in Fig. 1. An Additional file 2 gives tabulated information about the residues and bond lengths of each compound.

Table 2 Susceptibility details of E. coli isolates towards different antibiotics

\begin{tabular}{|c|c|c|c|c|}
\hline Strain & Source of isolates & Resistance details & Sensitive & MARI calculations \\
\hline E. coli strain 1 & Urine & $C A Z, A M X, A M C, C T N, A T, V A$, & CTR, CZ & 0.75 \\
\hline E. coli strain 2 & Urine & $C A Z, A M X, A M C, C T R, C T N, A T, V A, C Z$ & & 1 \\
\hline E. coli strain 3 & Urine & CAZ, AMX, AMC, CTR, CTN, AT, VA, CZ & & 1 \\
\hline
\end{tabular}

AMX Amoxicillin (25 mcg/disc), AMC Amoxicillin and clavulanic acid (20/10 mcg/disc), CTN Cefotetan (30 mcg/disc), AT Aztreonam (30 mcg/disc), CAZ Ceftazidime (30 mcg/disc), CTR Ceftriaxone (30 mcg/disc), CZ Cefazolin (30 mcg/disc) 


\section{Antibiotic susceptibility testing and phenotypic ESBL detection}

From susceptibility testing, it was observed that the clinical isolates of $E$. coli were resistant to most and sensitive to a few antibiotics. MARI calculations were also calculated which give an idea about the misuse of antibiotics leading to resistance. MARI calculations were calculated by dividing the number of antibiotics towards which the isolates showed resistance by the total number of antibiotics to which the isolates were subjected. Susceptibility results and MARI calculations are presented in Table 2. Furthermore, the phenotypic detection of ESBL was carried out by the double disc diffusion method. An Additional file 1 provides the diagrammatic representation of antibiotic susceptibility results and the phenotypic detection of ESBL production.

\section{Antibacterial activity through broth microdilution}

Three different concentrations of the extract (25, 50 and $100 \mu \mathrm{g} / \mathrm{ml}$ ) used to check the antibacterial effect provided promising results. $100 \mu \mathrm{g} / \mathrm{ml}$ of extract was most effective in controlling the growth of all $E$. coli strains and the effect was almost as good as the antibiotic. For $E$. coli strain 2, the extract was more effective compared to the antibiotic. $25 \mu \mathrm{g} / \mathrm{ml}$ of the extract was least effective and the growth of $E$. coli strains was almost similar to that of the untreated strains (Fig. 2).

\section{Biofilm inhibition}

Different concentrations of the extract used to check the biofilm inhibition potential against all the E. coli strains proved effective. $100 \mu \mathrm{g} / \mathrm{ml}$ of the extract was more effective than the antibiotic in inhibiting the biofilm formation whereas, $50 \mu \mathrm{g} / \mathrm{ml}$ of the extract and the antibiotic had a comparable effect on the biofilm inhibition in all the $E$. coli strains. $25 \mu \mathrm{g} / \mathrm{ml}$ of the extract was least effective (Fig. 3).

\section{DNA isolation and gene expression analysis by PCR}

The genomic DNA of ESBL producing strains of $E$. coli

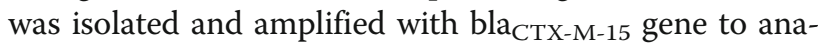
lyse the gene expression before and after treatment with CEA extract of $A$. paniculata. The results that were obtained after amplification displayed the downregulation of bla ${ }_{\mathrm{CTX}-\mathrm{M}-15}$ gene in treated strains 2 and 3 when compared to control. The intensity of bands (high, low and medium) was analyzed which corresponded to different gene expressions. ATCC strain of E. coli which was used as a negative control showed no expression at all (Fig. 4).

\section{Discussion}

A. paniculata has a long history of being utilized as an oriental and Ayurvedic medicine. Genus Andrographis belongs to the family Acanthaceae which includes around 40 species. A. paniculata is commonly known as the King of Bitters and is native to peninsular India and
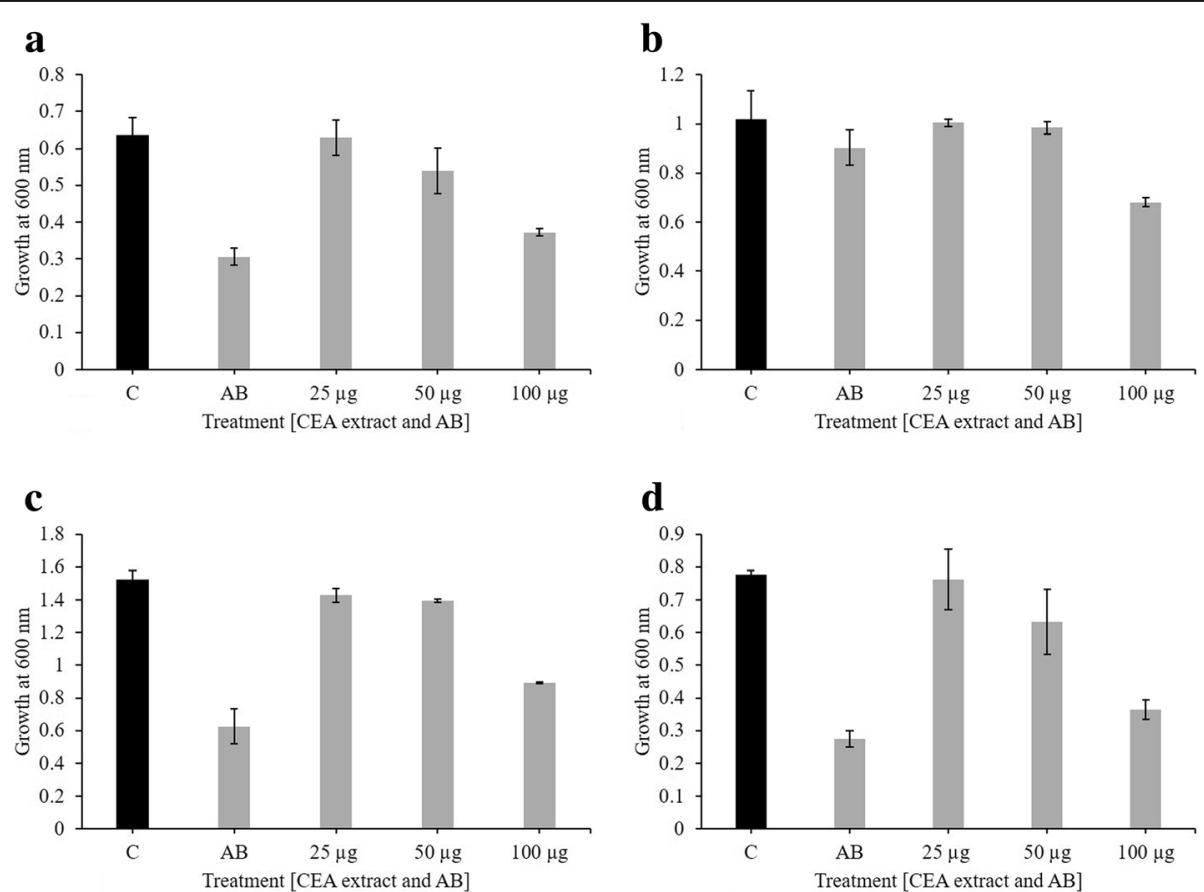

Fig. 2 Antibacterial activity of CEA extract through broth microdilution method. The picture shows the effect of 25,50 and $100 \mu \mathrm{g} / \mathrm{ml}$ of CEA extract on the growth of (a) E. coli strain 1 (b) E. coli strain 2 (c) E. coli strain 3 and (d) ATCC strain of E. coli 


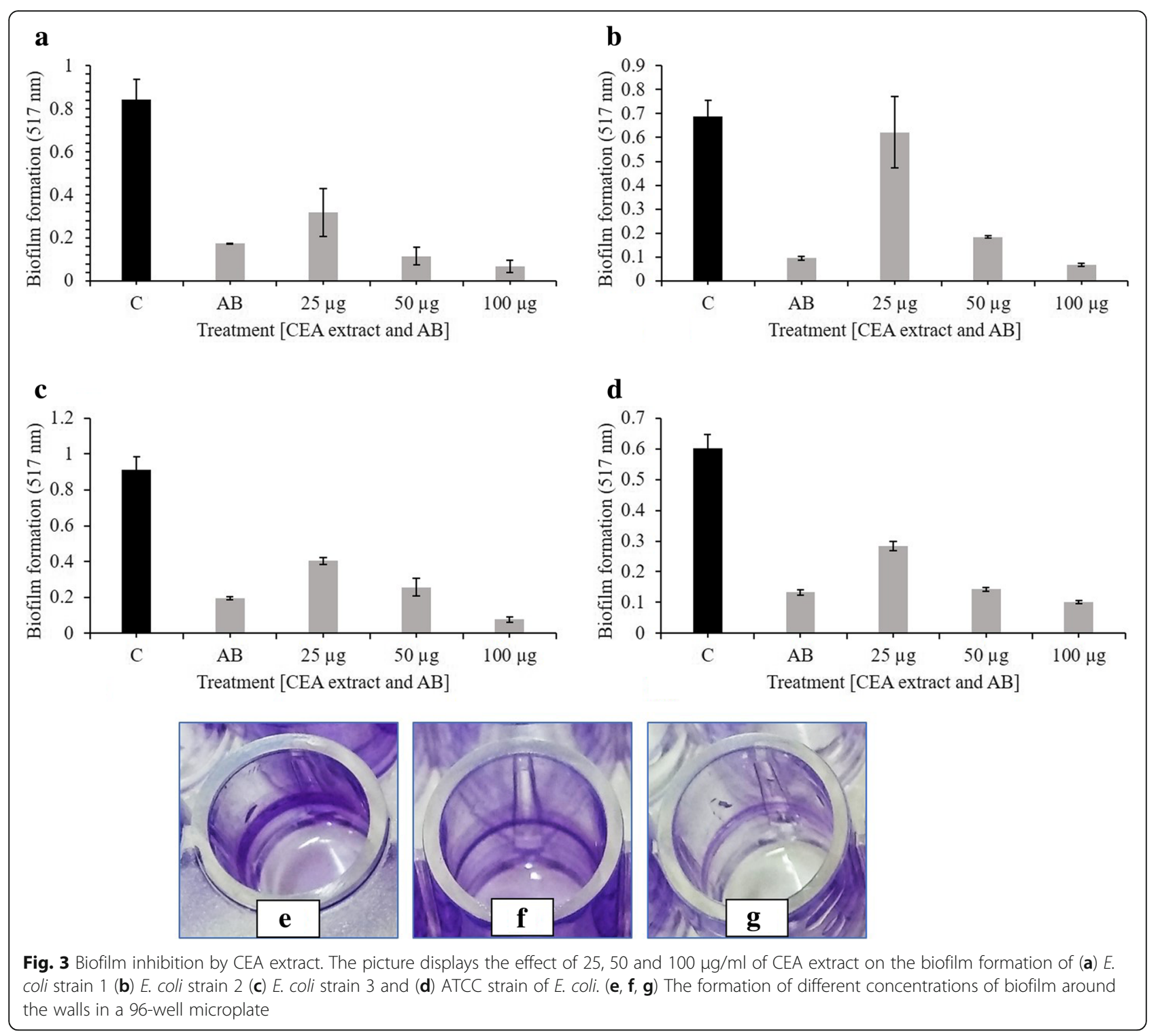

Sri Lanka. This plant also occupies different regions of Southeast Asia, China, America, West Indies and Christmas Island. The wide distribution of $A$. paniculata accounts for its medicinal values and its growth in most of the soil types. The aerial parts, as well as the roots of $A$. paniculata, have served the purpose of traditional medicine in countries like India, China, Thailand and some Southeast Asian countries. Extensive studies have been conducted by researchers across the world and particularly in Asia owing to the medicinal properties of $A$. paniculata. Phytochemical analysis of $A$. paniculata has unveiled a wide range of compounds such as labdane diterpenoid lactones, flavonoids and miscellaneous compounds. A. paniculata has also been reported to display a wide range of pharmacological properties [23]. The antibacterial properties of $A$. paniculata extracts have been reported in some previously carried out studies with different bacterial strains. Leelarasamee and co-workers reported a significant antimicrobial activity of crude extract of A. paniculata against Salmonella, Shigella, Escherichia coli, Streptococci, and Staphylococcus aureus at a concentration of $25 \mathrm{mg} / \mathrm{ml}$ [24]. An investigation conducted by Mishra and co-workers reported the growth inhibitory effect of ethanol extracts of aerial parts of $A$. paniculata against $E$. coli along with other Gram-positive and Gram-negative bacteria [25]. The present study focussed on utilizing the lesser concentration of CEA extract from $A$. paniculata where $100 \mu \mathrm{g} / \mathrm{ml}$ of the extract proved efficient in controlling the growth and biofilm formation in three different clinical strains and one ATCC strain of E. coli. $100 \mu \mathrm{g} / \mathrm{ml}$ of CEA extract showed comparable effects as that of the antibiotic in inhibiting the growth of E. coli strains and moreover, CEA was more effective in inhibiting the 


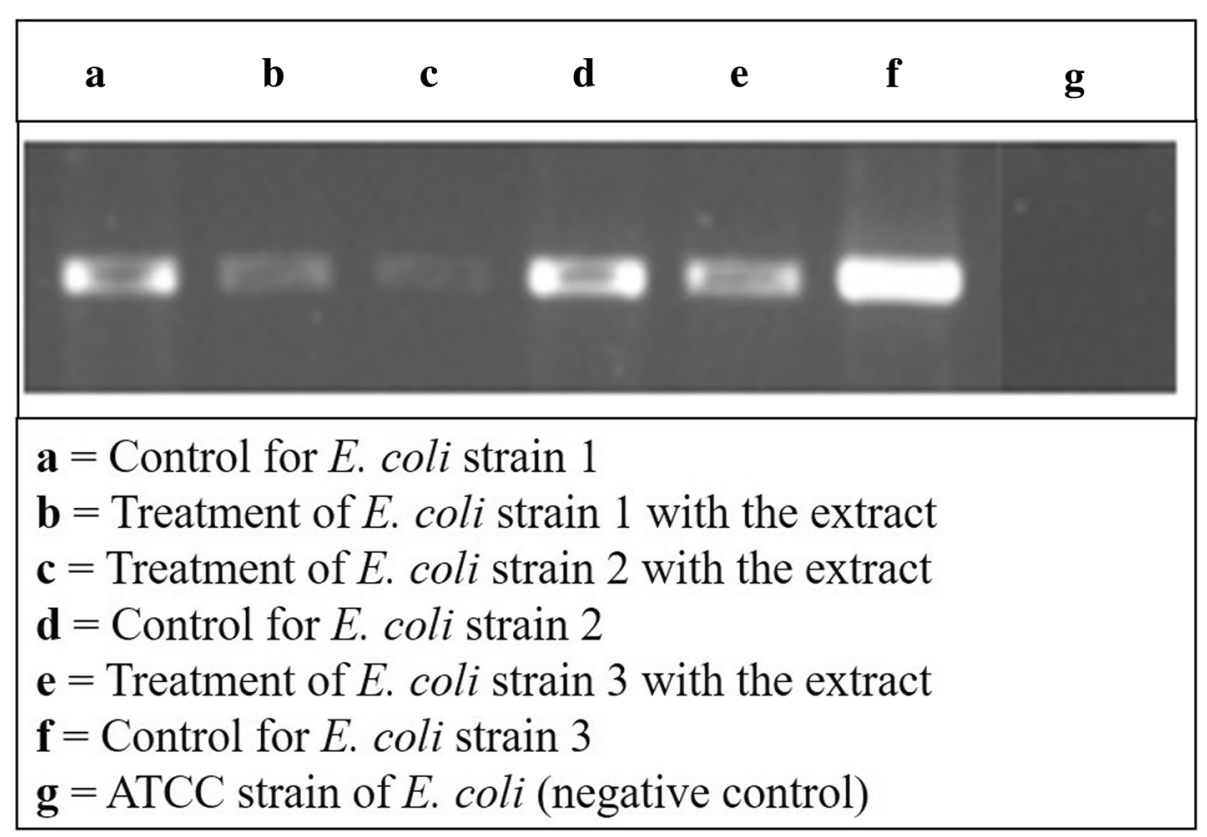

Fig. 4 Gene expression analysis through PCR. PCR amplification of gene encoding CTX-M-15 (410 bp) in control and treated E. coli strains. (a) control with strain 1; (b) CEA extract treatment with strain 1; (c) treatment with strain 2; (d) control with strain 2; (e) treatment with strain 3; (f) control with strain 3; (g) ATCC (negative control). The figure gives a description about the CTX-M-15 gene expression with and without the treatment of ethyl acetate extract

biofilm of E. coli strains compared to the antibiotic. A study conducted by Sule and co-workers reported the antibacterial activity of three different extracts (dichloromethane, methanol, and aqueous) of A. paniculata against 12 skin infection causing pathogenic bacterial strains. The extracts showed significant effects against all the tested bacterial strains at a concentration of 1000 , 500, and $250 \mu \mathrm{g} /$ disc [26]. Apart from the antibacterial and antibiofilm activity of CEA extract, molecular docking of 10 different bioactive compounds from $A$. paniculata with CTX-M-15 protein revealed a positive docking score. From the docking results, it can be hypothesized that bioactive compounds from $A$. paniculata may be a better source for inhibiting the CTX-M protein to control the ESBL producing E. coli strains. CTX-M beta-lactamases are a growing family of enzymes which are characterized by a selective hydrolysis of ceftriaxone and cefotaxime and more specifically ceftazidime. CTX-M-15 type ESBLs were first reported in K. pneumoniae, E. coli and human isolates of Enterobacter aerogenes from India and Japan. Since that time, CTX-M-15 type ESBLs have been recognized in Enterobacteriaceae strains from various countries like the United Kingdom, Bulgaria, Canada, Russia, Poland, Turkey and France. Extensive research has been conducted on CTX-M-15 type ESBLs in industrialized countries where E. coli and Klebsiella spp. are the most common cause of urinary tract infections [27]. In the present study, the molecular docking reports on CTX-M-15 and the bioactive compounds from $A$. paniculata are the first to be reported.

ESBL production by Enterobacteriaceae strains has been a cause of resistance against various antimicrobial agents which in turn presents a hindrance in clinical practice making it difficult to treat infections [28]. The resistance mechanisms that ESBL strains have developed need to be keenly observed so that novel and effective antimicrobial agents can be discovered and designed properly [29]. In the present study, the variable expression of a gene encoding CTX-M-15 was observed when treated with CEA extract of $A$. paniculata in 3 different ESBL producing strains of $E$. coli. The study presented an overview of the CEA extract of $A$. paniculata and its strong ability to inhibit the production of ESBL at the molecular level which may act as an alternative to fight the bacterial resistance.

The overall significance of the present study lies in the fact that ESBL producing strains are developing at a fast pace which in turn increases the percentage of antibiotic resistance. In order to stop this increasing menace of antibiotic resistance, a continuous research to find more novel antibacterial agents needs to be carried out. In this study, we presented an approach towards finding a possible way to stop the ESBL producing clinical strains of E. coli and since CTX-M-15 type ESBLs are more prevalent in India and more specifically the southern part, hence the strains positive for CTX-M-15 were chosen 
for this study. Moreover, the literature about A. paniculata which gives an idea about the overwhelming applications of this very plant in the medicinal field made us choose this plant for the present study.

\section{Conclusions}

This study proved an effective and an economic way of controlling the growth and biofilm formation in clinical isolates of E. coli. Phytochemical and FTIR analysis helped to know about the presence of metabolites and functional groups present in the extract. Susceptibility testing presented the resistance patterns of E. coli clinical isolates towards different antibiotic formulations. Antibacterial and antibiofilm activity at lesser concentrations of CEA extract proved effective. CEA extract was also able to downregulate the expression of a gene encoding CTX-M-15. Finally, in-silico studies of 10 different bioactive compounds from $A$. paniculata with CTX-M-15 provided the residues and bong lengths with a positive docking score.

\section{Limitations}

- The antibacterial activity of CEA extract can extend to a wide range of other drug-resistant bacteria

- Molecular docking can extend to other bioactive compounds

- Different extracts of A. paniculata can be prepared and evaluated further

- Biofilm inhibition assay can extend to more bacterial isolates

\section{Additional files}

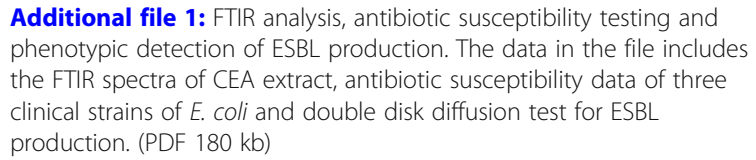
phenotypic detection of ESBL production. The data in the file includes the FTIR spectra of CEA extract, antibiotic susceptibility data of three clinical strains of E. coli and double disk diffusion test for ESBL production. (PDF $180 \mathrm{~kb}$ )

Additional file 2: Residues and bond lengths of 10 bioactive compounds of A. paniculata docked with CTX-M-15. The data in the file includes the tabular representation of the docking results showing the residues and bond lengths of 10 bioactive compounds of $A$. paniculata with CTX-M-15. (PDF $15 \mathrm{~kb}$ )

\footnotetext{
Abbreviations

ALA: Alanine; AMC: Amoxicillin and clavulanic acid (20/10 mcg/disc); AMX: Amoxicillin (25 mcg/disc); ARG: Arginine; ASN: Asparagine; AT: Aztreonam; ATCC: American type culture collection; CAZ: Ceftazidime; CEA: crude ethyl acetate; CLSI: Clinical Laboratory Standard Institute; CTN: Cefotetan; CTR: Ceftriaxone; CTX-M-15: active on CefoTaXime; CZ: Cefazolin; DNA: Deoxyribonucleic acid; ESBL: extended spectrum $\beta$ lactamase; FTIR: Fourier transform infrared spectroscopy; GLY: Glycine; HIV: Human immunodeficiency virus; LBA: Luria-Bertani agar; MARI: multiple antibiotic resistance indices; PCR: polymerase chain reaction; PDB: protein databank; PRO: Proline; SER: Serine; THR: Threonine; TYR: Tyrosine
}

\section{Acknowledgements}

The authors of this paper are extremely thankful to the School of Life Sciences, BSA Crescent University for encouraging the research scholars are other students to work freely without any hurdles. Mr. Saroj Kumar Sah is thankful to BS Abdur Rahman Crescent Institute of Science and Technology for his Junior Research Fellowship.

\section{Funding}

This work has been carried out in School of Life Sciences, BSA Crescent Institute of Science and Technology, Chennai, India. There has been no funding for this work but the institute management has been providing a monthly fellowship to Mr. Saroj Kumar Sah, one of the authors of this paper.

\section{Availability of data and materials}

The datasets used and/or investigated during the present study are accessible from the corresponding author on reasonable request.

\section{Author's contributions}

UR drafted the manuscript and critically revised it. PS designed the molecular docking work and performed it. AP performed the experiments. SKS designed the microbiology experiments and interpreted the data. SH designed the whole idea of this work and critically revised it. All authors read and approved the final version of the manuscript.

\section{Ethics approval and consent to participate}

ESBL strains of E. coli were obtained from Tagore Medical College, Chennai, India after proper approval from BS Abdur Rahman Crescent Institute of Science and Technology ethical committee (Ref. no. BSAU: REG-OFF: 2016/ 02SLS). The informed consent was obtained and maintained by Tagore medical college. (To maintain the confidentiality this information cannot be maintained by our university)

\section{Consent for publication}

Not applicable

\section{Competing interests}

The authors declare that they have no competing interests.

\section{Publisher's Note}

Springer Nature remains neutral with regard to jurisdictional claims in published maps and institutional affiliations.

Received: 3 May 2018 Accepted: 22 August 2018

Published online: 03 September 2018

\section{References}

1. Nayak BK, Pavithera S, Nanda A. Soxhlet extraction of leaf extracts of Andrographis paniculata and its antibacterial efficacy against few pathogenic bacterial strains. Pharm Lett. 2015;7:250-3.

2. Hossain MS, Urbi Z, Sule A, Rahman KMH. Andrographis paniculata (Burm. F.) wall. Ex Nees: a review of Ethnobotany, Phytochemistry, and pharmacology. Sci World J. 2014; https://doi.org/10.1155/2014/274905.

3. Sheeja K, Kuttan G. Activation of cytotoxic T lymphocyte responses and attenuation of tumor growth in vivo by Andrographis paniculata extract and andrographolide. Immunopharmacol Immunotoxicol. 2007;29:81-93.

4. Calabrese C, Berman SH, Babish JG, Ma X. A phase I trial of andrographolide in HIV positive patients and normal volunteers. Phytother Res. 2000;14:333-8.

5. Yoopan N, Thisoda P, Rangkadilok N, Sahasitiwat S. Cardiovascular effects of 14-deoxy-11,12-didehydroandrographolide and Andrographis paniculata extracts. Planta Med. 2007;73:503-11.

6. Trivedi NP, Rawal UM, Patel BP. Hepatoprotective effect of andrographolide against hexachlorocyclohexane-induced oxidative injury. Integr Cancer Ther. 2007:6:271-80.

7. Siripong P, Kongkathip B, Preechanukool K, Picha P. Cytotoxic diterpenoid constituents from Andrographis paniculata, nees leaves. J Sci Soc Thailand. 1992;18:187-94.

8. Zaidan MR, Noor Rain A, Badrul AR, Adlin A. In vitro screening of five local medicinal plants for antibacterial activity using disc diffusion method. Trop Biomed. 2005;22:165-70 
9. Bobbarala V, Rao PK, Rao GS, Aryamithra D. Bioactivity of Andrographis paniculata against selected Phytopathogens. J Pharm Res. 2009;2:480-2.

10. Trease GE, Evans WC. Pharmacognosy: A physician's guide to herbal medicine. 13th ed. London: Bailliere Tindall; 1989. p. 176-80.

11. Harborne JB. Phytochemical methods. London: Chapman and Hall; 1973. p. 113.

12. Sofowora A. Medicinal plants and traditional medicine in Africa. Ibadan: Spectrum Books Ltd.; 1993. p. 289.

13. Eberhardt TL, Li X, Shupe TF, Hse CY. Chinese tallow tree (Sapium sebiferum) utilization: characterization of extractives and cell-wall chemistry. Wood Fiber Sci. 2007:39:319-24.

14. Hazra KM, Roy RN, Sen SK, Laska S. Isolation of antibacterial pentahydroxy flavones from the seeds of Mimusops elengi Linn. Afr J Biotechnol. 2007;6: $1446-9$.

15. Sasidharan $S$, Chen $Y$, Saravanan D, Sundram KM. Extraction, isolation and characterization of bioactive compounds from plant extracts. Afr J Tradit Complement Altern Med. 2011;8:1-10.

16. Cahill ST, Cain R, Wang DY, Lohans $C T$, Wareham DW, Oswin HP, Mohammed J, Spencer J, Fishwick CW, McDonough MA, Schofield CJ, Brem J. Cyclic boronates inhibit all classes of $\beta$-Lactamases. Antimicrob Agents Chemother. 2017;61:e02260-16. https://doi.org/10.1128/AAC.02260-16.

17. Holger C, Christian B, Matthias R, Thomas L. FLEXE: Efficient molecular docking considering protein structure variations. J Mol Biol. 2001:308:377-95.

18. Ekwealor AP, Ugwu MC, Ezeobi I, Amalukwe G, Ugwu BC, Okezie U, Stanley C, Esimone C. Antimicrobial evaluation of bacterial isolates from urine specimen of patients with complaints of urinary tract infections in Awka, Nigeria. Int J Microbiol. 2016;2016:1-7.

19. National Committee for Clinical Laboratory standards. Performance standards for antimicrobial disc susceptibility tests. Approved standard M2A5, vol. M100 S17. Villanova: National Committee for Clinical Laboratory Standards; 2012. p. 22.

20. Jorgensen JH, Turnidge JD, Washington JA. Antibacterial susceptibility tests: dilution and disk diffusion methods. In: Murray PR, Baron EJ, Pfaller MA, Tenover FC, Yolken RH, editors. Manual of clinical microbiology. 7th ed. Washington: ASM Press; 1999. p. 1526-43.

21. O'Toole GA. Microtiter dish biofilm formation assay. J Visualized Exp. 2011; 47:2437.

22. Dashti AA, Jadaon MM, Abdulsamad MA, Dashti HM. Heat treatment of Bacteria: a simple method of DNA extraction for molecular techniques. Kuwait Med J. 2009:41:117-22.

23. Okhuarobo A, Falodun JE, Erharuyi O, Imieje V, Falodun A, Langer P. Harnessing the medicinal properties of Andrographis paniculata for diseases and beyond: a review of its phytochemistry and pharmacology. Asian Pac J Trop Dis. 2014;4:213-22.

24. Leelarasamee A, Trakulsomboon S, Sittisomwong N. Undetectable antibacterial activity of Andrographis paniculata (Burma) wall, Ex ness. J Med Assoc Thai. 1990;73:299-304.

25. Mishra US, Mishra A, Kumari R, Murthy PN. Antibacterial activity of ethanol extract of Andrographis paniculata. Ind J Pharm Sci. 2009:71:436-8.

26. Sule A, Ahmed QU, Samah OA, Omar MN. Screening for antibacterial activity of Andrographis paniculata used in Malaysian folkloric medicine: a possible alternative for the treatment of skin infections. Ethno Leaflets. 2010;4:445-56.

27. Bialvaei AZ, Pourlak T, Aghamali M, Asgharzadeh M, Gholizadeh M, Kafil HS. The prevalence of CTX-M-15 extended-spectrum $\beta$-lactamases among Salmonella spp. and Shigella spp. isolated from three Iranian hospitals. European journal of. Microbiol Immunol. 2017;7:133-7.

28. Shaikh S, Fatima J, Shakil S, Rizvi SMD. Antibiotic resistance and extended spectrum beta-lactamases: types, epidemiology and treatment. Saudi J Biol Sci. 2015;22:90-101.

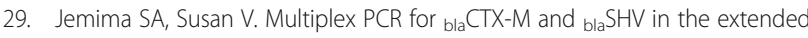
spectrum beta- lactamase (ESBL) producing gram-negative isolates. Ind J Med Res. 2008;128:313-7.

Ready to submit your research? Choose BMC and benefit from:

- fast, convenient online submission

- thorough peer review by experienced researchers in your field

- rapid publication on acceptance

- support for research data, including large and complex data types

- gold Open Access which fosters wider collaboration and increased citations

- maximum visibility for your research: over $100 \mathrm{M}$ website views per year

At $\mathrm{BMC}$, research is always in progress.

Learn more biomedcentral.com/submissions 